\title{
The International Institute of Tropical Forestry
}

\author{
by Frank $\mathrm{H}$. Wadsworth ${ }^{1}$
}

Forestry began in Puerto Rico with 25 years of reservation and management under Spanish dominion prior to 1898 . United States entry led to the creation of the 5,000-ha Luquillo Forest Reserve in 1903, based on lands formerly of the Spanish Crown. Staffing was delayed until 1917, after the area had become a National Forest (now titled the "Caribbean NF"). From 1918 to 1956 the federal Forest Service also managed a system of public forests under the Puerto Rico Department of Agriculture, now termed "State Forests."

During the 1930s, abandoned farmlands added to the public forest system required extensive reforestation. Technical problems led in 1939 to the creation in Rio Piedras of the Tropical Forest Experiment Station. This, the predecessor of the present Institute, has operated in cooperation with the University of Puerto Rico. From 1941 the Station was assigned management of the State Forest system until 1956 and the Caribbean National Forest until 1974.

In addition to its responsibilities for land administration and management, the Station was faced with glaring technical concerns. There was an immediate need to determine what could be learned from thousands of hectares of recent forest plantations. These were on sites ranging from sea level to $1,200 \mathrm{~m}$ elevation, with rainfall from 80 to $500 \mathrm{~cm}$ annually, and soils from organic mucks to coarse granitic sands and fine clays. More than 100 hardly known tree species, both natives and exotics, had been tried. Deficiencies were experienced in both propagation and species adaptability. Virtually nothing was known of the National Forest, and its management was still incipient. Moreover, there was no other forestry research center in the entire region. To meet this situation, the following were undertaken: - A tropical forestry library and an herbarium and wood collection of local species were begun.

- The 750-species tree flora (including principal exotics) of Puerto Rico and the U.S. Virgin Islands was described and published.

- Receptivity of common post species to preservative treatment and resultant extended service life was determined.

- Machining properties of the common native timbers were determined.

- Forest planting sites and planted tree species performance were classified by rainfall, slope, soil type, and planting season.

- Tree growth measurements were begun in representative forests and promising timber plantations throughout Puerto Rico.

The National Forest land area was segregated for research, watershed protection, wildlife habitat, and recreation. The remaining area of timber production potential was inventoried, compartmented, and placed under area-control regulation of harvest, followed by repeated liberation of future crop trees.

New tree species were propagated and test planted.

Manuals for nursery practice and urban tree planting were produced.

For 24 years a trilingual, quarterly technical journal, The

${ }^{1}$ Research Forester, International Cooperation, USDA Forest Service, International Institute of Tropical Forestry, PO Box 25000, San Juan PR 009285000 , USA.
Caribbean Forester, presented the results of local and other Caribbean forest research.

Sixteen three-month tropical forestry short courses were offered to foresters from other tropical countries.

An intensive ecosystem assessment within the National Forest (by then also designated the Luquillo Experimental Forest) was completed by some 80 scientists, resulting in a major book.

So much for the first forty years. The library, with some 200 journals, has grown to one of the best in the region, with CDROM abstract retrieval service. The Luquillo Experimental Forest became a rain forest unit in a nationwide network of Long Term Ecological Research sites, with investigations conducted jointly with the University of Puerto Rico. Policy and program coordination and mutual assistance now exist with eight local government agencies and fifteen non-governmental conservation groups. A new, expanding program provides guidance and financial incentives to local authorities for urban forestry. Research partnerships now exist with some fifty other institutions.

Experiments continue in both public and private forests of Puerto Rico and in the Estate Thomas Experimental Forest on the island of St. Croix. Institute staffing has grown to 42 scientists, other professionals, and technicians. Hundreds of students have been introduced to and supervised through diverse scientific projects. More than 80 publications were produced by the staff and cooperators during 1996.

The currently stated mission of the Institute is to "develop and exchange knowledge critical to sustaining tropical ecosystem benefits." Within this broad scope, the following projects illustrate the diversity of the work in progress:

- The carbon cycle of tropical forests at the local, regional, and global levels.

- The influence of tropical deforestation on soil emissions and atmospheric chemistry.

- Global changes attending selective timber harvesting in Brazil.

- The socioeconomic evaluation of forest water resources.

- Consolidation of mahogany information germane to the CITES controversy.

- Identification of the trees of the Tapajos Forest, Brazil, a published manual.

- The identification and significance of fungi in tropical forests.

- Characterization of the impact of hurricanes and public recreation on tropical forests.

- Development of forest management practices that favor sustainability and environmental values.

- Developing secondary forests for local populations.

- Rehabilitating degraded forest lands, including natural species enrichment.

- Assessment of tree growth competition and stand development over long periods in wet, moist, and dry forests.

- The development of methods to measure and compare the magnitude, frequency, and forest recovery periods from landslides, tree-falls, droughts, hurricanes, and selective timber harvesting.

- The hydrological and nutrient budgets of the Luquillo Forest.

- Minimum streamflow levels required to maintain the ecological integrity of the aquatic environment. 
- Winter habitat requirements of migratory birds, including comparison of sun-grown and shade-grown coffee plantations in the Dominican Republic.

The international activities of the Institute have included direct participation with the Silvicultural Study Group of FAO's North American Forestry Commission, and the Regional Research Committee of the Latin American Forestry Commission. Through two full-time forestry advisors in the Caribbean, the Institute program is coordinated with that of USAID. Close liaison has long existed between the Institute and the Centro Agronómico Tropical de Investigación y Enseñanza (CATIE) in Costa Rica, and the Latin American Forestry Institute in Venezuela. The text of ISTF NEWS, the trilingual, technical newsletter of the International Society of Tropical Foresters has for 18 years been generated at the Institute. The Institute has sponsored eight biannual meetings of the foresters of the Caribbean. The Institute has also sponsored a limited grant program for forestry projects in the region.

An outgrowth of international contacts has been a continuous sequence of staff consultancies. Subjects include conservation policies, research planning, land use, timber management, silviculture, reforestation, line planting, timber sale procedures, and community development. These have occurred in virtually all of the Caribbean islands, Mexico, Belize, Guatemala, Honduras, Nicaragua, Costa Rica, Panama, Colombia, Venezuela, Brazil, Ecuador, Peru, Paraguay, and Sarawak.

An Institute Cooperative Forestry Program serves to strengthen public and private initiative within Puerto Rico and the Virgin Islands toward environmental education, community organization, reforestation, and urban forestry. This is accomplished through technical guidance, improved planning, and governmental incentives.

With the government of Canada, the Institute has also been active through the FAO North American Forestry Commission. The Commission's Silvicultural Study Group, with Canadian and IITF participation, has produced since 1978 a directory of North American tropical silviculturists, silvical descriptions of useful trees of common interest, and has promoted four workshops on different subjects for the foresters of tropical Mexico. Canada also contributed some of the support for a recent meeting of the Caribbean foresters.

The Institute invites Canadian foresters and related scientists to participate in joint projects in a benign winter climate. An Annual Letter with a list of available publications can be sent upon request. We may be reached at P.O. Box 25000, San Juan, Puerto Rico 00928-5000, telephone (787) 766-5335, Fax (787) 766-6302. Our Web Page may be accessed at: <http://www.fs.fed.us/global/iitf/welcome.html>

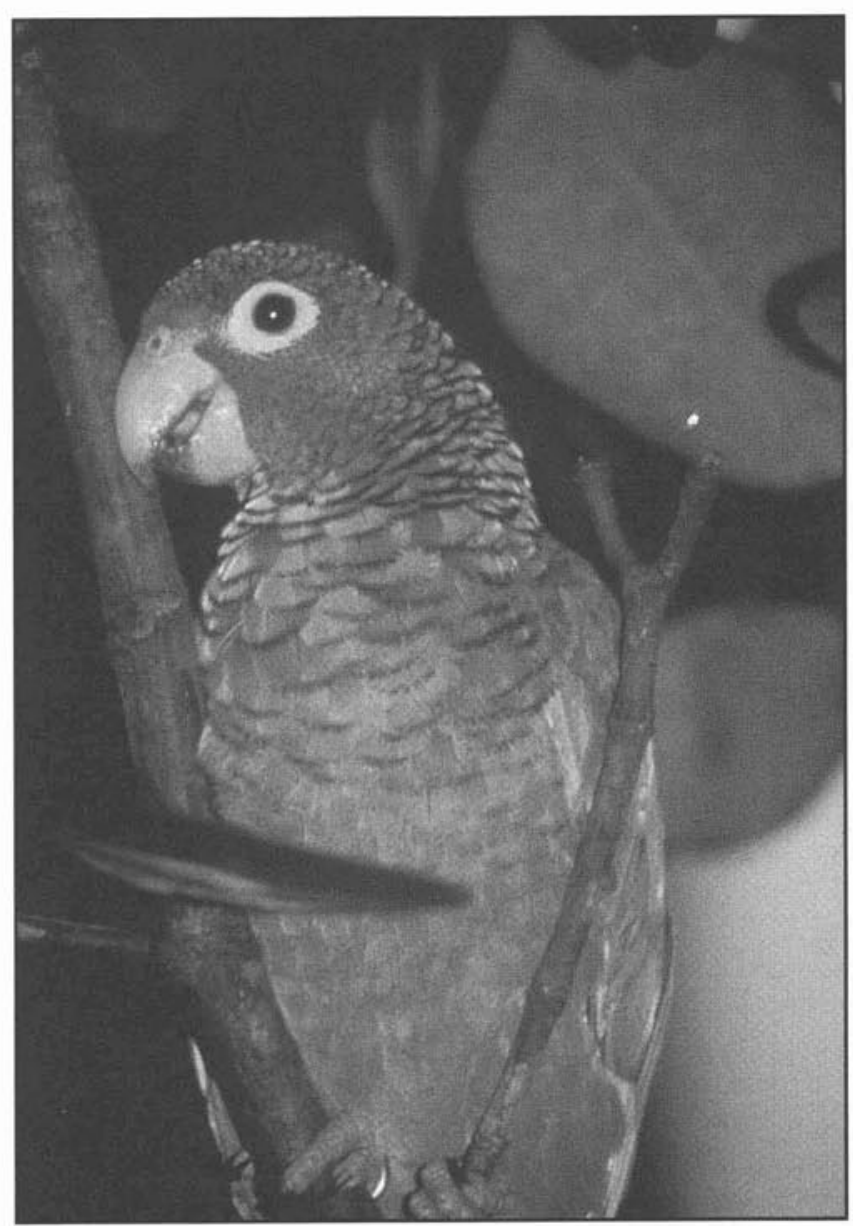

The Puerto Rican Parrot (Amazona vittata) has played an important role in the Institute's priorities, by Tomas Carlo, USFWS Field Office. 